\title{
The Brain as Peace Maker: Healing Methods Based on Nature, Art, Science, Fractal Geometry, Brain Research, Yoga etc.: Part I
}

\author{
Konrad Frischeisen* \\ New Frontiers in Science, Germany
}

*Corresponding author: Konrad Frischeisen, New Frontiers in Science

Bildungsgesellschaft mbH, (als gemeinnützig anerkannt) Munich/Germany.
Received Date: July 16, 2019

Published Date: July 18, 2019

\section{Introduction}

The Humboldt Year 2019 causes reflections on Humboldt's 'Kosmos', evoking the question, how it can lead to healing approaches with role models, Nobel Laureates and Mandelbrot's. The Fraktal Geometry of nature. Honoring Humboldt that way in the spirit of Berta von Sutt-ner, Jane Goodall, Francoise Barré-Sinoussi, Barbara McClintock, Rita Levi-Montalcini, Christiane Nüsslein-Volhard, Ruth Pfau, Gerty Spies, Roger Sperry, Max Delbrück, John Eccles, Viktor Frankl, Boris Cyrulnik, Eckart Altenmüller, Richard Davidson, Eric Kandel, Jon Kabat-Zinn, Martin Keck, Georg Kreutzberg, Daniel Levitin, Salvatore Luria, Linus Pau-ling, Albert Schweitzer, Roger Walsh, Rajesh Mehta, Rabindranath Tagore \& Co. may help.

Regarded as 2nd Christoph Columbus Humboldt is excellently valued in Peter Watson's book 'The German Genius', encouraging us to regard him in the tradition of such famous scholars as Aristotle and Leibniz. According to Watson's book Alexander v. Humboldt 'was in his days as famous as Napoleon', helping 'to advance the careers of many young scientists, But perhaps the most enduring monument is, that more places around the world are named after Humboldt than anyone else, thirty five in all, one city in Mexico, one in Canada, ten in the United States, nine bodies of water (including the Humboldt Current in the Pacific Ocean), seven mountains and glaciers (incl. Humboldt Mountains in China and New Zealand), four parks or forests (incl. the Humboldt national park in Cuba). There is also the Mare Humboldtianum on the moon.' President Jefferson received him warmly and later he was regarded as Europe's minister of Education and Cultural Affairs as well as the Aristotle of modern times.

A.V.Humboldt supported the architect Schinkel generously with his best contacts in Paris to give Berlin beautiful buildings. Schinkel felt much inspired by the beauty of Mozart's music, which Albert
Einstein considered according to Peter Bucky's book on him as inside beauty of the universe. Schinkel and prince Ludwig, becoming later king Ludwig I of Bavaria, had the chance to meet Alexander's brother Wilhelm von Humboldt, who created an university model, evoking best results in the students' up lifting to leading universal educated personalities.

That Germany caused in spite of it two world wars is in the author's view not yet completely understood, although Max Picard gave in, Hitler in uns selbst'best explications, likewise Sri Aurobindo, valued by the Nobel Laureates Rolland, Tagore, Pearl S. Buck and Gabriela Mistral. The artist Friedensreich Hundertwasser reinforced hopes, that the Fractal Geometry of Nature, Sperry's splitbrain model and the knowledge of leading researchers and Nobel Laureates may give new insights in deficiencies of geometry and brain activities of the Nazis. Mandelbrot discovered at first self similar structures in the human language before he found them in nature, for example in trees, seashores, rivers, mountains, waves, forests, clouds etc. He mentioned to be influenced by Aristotle and Leibniz, recalling Prof. Kurt Huber's book,Leibniz, Philosoph der universalen Harmonie'into the author's mind. Prof. Huber was men-tor of the student movement, Die weisse Rose' (The white rose), striving for harmony, truth and peace in the Nazi Regime. Prof. Huber and some engaged students of this movement like Sophie Scholl and her brother Hans Scholl, a medical student, were executed by the Nazis.

Prof. Huber worked until he was murdered by Nazis for his book on Leibniz, hoping to recall the good German and his work, based on laws of nature, into the mind of future generations. The Geschwister-Scholl-Platz and Prof.-Huber-Platz are places in front of the LMU, Ludwig-Maximilians-Universität, right and left side of 
the Ludwigstraße in München, Munich, where the author started studies and researches looking for healing results beyond the Nazi ideology. Supported by his father Alfred, an inventor and aeroplane technician, he venerated Otto von Habsburg and had the chance to listen personally to his lecture on his ideas of the future of the USA in Cannes about 49 years ago and to exchange some personal words and ideas with him. About one year later the author was glad to meet Werner Heisenberg personally and to give him some helpful hints for his lecture in honour of an anniversary of the LMU. Heisenberg's books like,Schritte über Grenzen' (Steps beyond Fr ontiers) and, Der Teil und das Ganze' (The part and the whole) were as inspiring for the author's work as Binnig's lecture and book. Heisenberg valued Alexander v. Humboldt, became president of the Alexander v. Humboldt Foundation, recognizing the responsibility of researchers after World War II and after the desaster caused by atomic bombs in Hiroshima and Nagasaki. He saw in 'The little Prince' of the pilot and poet de Saint-Exupéry a helpful example for he had learned to see with the heart. Nobel Laureate Eigen compared Heisenberg in 'Jenseits von Ideologien und Wunschdenken' (Beyond Ideologies and Wishful Thinking) after having shown a painting of Copernicus with Mozart, presenting the results of Nobel Laureate Sperry's split brain research, according to an overview of Nobel Laureate Eccles, which the author translated and summarized that way: Dominant Hemisphere and Subdominant Hemisphere connection to the consciousness, unconscious action verbal, logical constructive, comprehending, musically, visually, visual way of capturing, analytically, sequential, arithmetic, synthetically, holistic, geometric

A lecture of the Nobel Laureate Gerd Binnig in 1989, some weeks before the iron curtain and the wall in Berlin was falling, held in the City Museum of Munich, with the title, Sind wir noch zu retten?' / Can we still be saved? and Binnig's book. Aus dem Nichts'/ From nothing, Über die Kreativität von Natur und Mensch'/On creativity on nature and man, reinforced the author's hope, that the creativity of nature and man can lead to holistic healing approaches. Binnig's book was helpfully leading to a deeper understanding of nature, man and his brain, giving impulses for studying Sperry's book 'Science and Moral Priority', H. Reeves, Schmetterlinge und Galaxien'(Butterflies and Galaxies) and Mandelbrot's 'The Fractal Geometry of Nature' as well as some books of Prof. Hermann Haken on synergetics, based on his Laser Theory. That way the summer academy 2000 in the EU Project Euro-House was prepared and realized with help of the author in cooperation with leading researchers, teachers, students and pupils among them Dr. Prince Albert von Sachsen (Saxonia), Prof. E.-P. Fischer and Prof. Karl Leo.

In the year 2001 the author prepared in dialogue with leading researchers, among them Nobel Laureate Wolfgang Ketterle and the Prof. Walter Blum, Wolfgang Heckl, Harald Lesch, Eck-hard Wolf and Martin Hrabé de Angelis an interdisciplinary concept, presented 2002 in 'New Frontiers in Science'symposia in the Goethe Institut München Sonnenenstr. and at the LMU. The New Frontiers in Science Symposium 2002 at the LMU, Ludwig-MaximiliansUniversität was supported by the former prorector of the LMU, Prof. Hans-Georg Liebich. He and Prof. Impressum: Copyright
2019, Konrad Frischeisen, Healing methods based on nature, art, science, fractal geometry, brain research, yoga etc. New Frontiers in Science Bildungsgesell-schaft $\mathrm{mbH}$, all rigths and errors reserved, frischeisen@ehims.de ISBN: 978-344465-14-2.

Hans-J. Warnecke, author of Die Fraktale Fabrik'and President of the Fraunhofer Gesell-schaft in that time, Dr. Prinz Albert von Sachsen, Prof. Walter Blum, Prof. Hrabé de Angelis and Prof. Noel Lenski, Cornell University (guest of the Alexander von Humboldt Foundation) held excellent lectures in that event. Likewise did Detlef Frank, former chief engineer of BMW and Jörn Schlichting, engineer in that time in charge of the Trans rapid Project Siemens. The DAAD Summer Academy "New Frontiers in Science", organized in the years 2003-2005 attracted young researchers from all parts of the world. Asked by Prof. Ketterle, MIT, Prof. Bernd Widdig suggested 2004 to organize the DAAD Summer-Academy in the spirit of Hum-boldt. In his view Humboldt, who valued Pestalozzi, created the best educational concept.

Following Prof. Widdig's advices the DAAD Summer Academy New Frontiers in Science 2005 was opened in the Honory Hall of the German Museum. The DAAD Journal German Summer Academies 2005 "New Frontiers in Science" Munich Summer Academy desc ribed it that way: The 2005 Summer Academy on "New Frontiers in Science" which K. Frischeisen developed is divided in 2 courses. It follows the 2000 Summer Academy held as part of the EU EuroHouse project and was run for the first time in the DAAD "German Summer Academy" programme in 2003 with international researchers, including the 1991 and 1988 Nobel Lau-reates in Chemistry Richard Ernst (ETH) Zürich and Robert Huber (MaxPlanck Institut for Biochemistry), Nobel Laureate for Medicine 1995, Christiane Nüsslein-Volhard will also take part in 2005.Course I begins with elementary particle physics... with the history of the ori-gins of the universe, of Earth, of life and its development, completed by the latest findings in physics, chemistry, biology and medicine. Its focuses are nanotechnology and biotechnology, information and laser technology, nanosystembiology, geobiosystem research, quantum com-puting, genetic, genome and protein research, plus mitochondria and molecular machines. Course II offers a science programme with excursions to the MPIs of Physics, Extraterrestrial Physics and Quantum Optics, where scientific highlights are presented, such as quantum computing, the Bose-Einstein-Condensate/2001 Nobel Prize in Physics for Wolfgang Ketterle/ and the Scanning Tunneling Microscope/1986 Nobel Price in Physic for Gerd Binnig.

In the $2^{\text {nd }}$ part of this article the mentioned Summer-Academy will be reflected with names of the participating researchers and the IMPRS Interdisciplinary Symposium "New Frontiers in Science", based on the sketched 'New Frontiers in S cience'concept, supported by Prof. Gabriela von Habsburg \& Co. and further excellent researcher like the Prof. Herbert Walther, Martin Faessler, Walter Neupert, Michael Groll, Wolfgang Parak, Reinhard Putz \& Co. with leading researchers, among them the Nobel Laureates Arber ( medicine), Ernst (chemi-stry), Huber (chemistry), Ketterle (physics), the Leibniz Price Laureates Siegfried Bethke, Günther 
Hasinger and Ferenc Krausz, the Prof. Marti n Heisenberg, Karl-Heinz Maurer, E.P. Fischer, Georg Kreutzberg, Dr. Helmut Rechenberg, the former IMPRS students Dr. Carlos Acevedo, Lea Sharp, Andrea Golla \& Co. succeeded to motivate ca. 400 young international reseachers from nearly all important university towns of Germany to join the IMPRS Interdisciplinary Symposium 'New Frontiers in Science'in the years 2008, 2009 and 2010.

Personal contact with the lecturers were established., among them Prof. Aaron Bernstein from the Havard Medical School, who edited with Eric Chivian 'Sustaining Life', showing in his lecture, how our health is depending on the biodiversity of the earth. Our planet appeared in the eyes of Neil Armstrong or one of his collegues after having landed on the moon 50 years ago, like a beautiful pearl in front of dark velvet. It raised the desire to protect the biosphere of our earth, appearing to him as home, flying back, if it is well remembered in this Humboldt year, inspired by Dr. Olympia Kyriopoulos, who was glad to meet N. Armstrong personally. This seems to have stimulated Olympia to send messages with paintings from children into the space, helping perhaps to bring the micro cosmos into harmony with the order of the ma-cro cosmos. Like the little Prince Olympia did not see frontiers looking from the space to the earth. Her project, the research performance Weltentöchter/ daughters of the world, of Charis Nass and the Münchner Model of Prof. Andreas de Bruin are inspiring examples, likewise the project of Dr. med Wolfgang Schweiger, Asia Deutschland e.V. for helping children in Tibet.

The roof of our earth is reminding verses of the Bavarian King Ludwig I in honor of Mozart: ...wie auf des Olympos Höhen der Götter Jugend ewig blüht Wird blühend, was Du schufst bestehen, bist Sonne, welche ewig glüht...' König Ludwi g I von Bayern An Mozart ('...how on the heights of the Olympus, the youth of Gods blossoms for ever Will blossom, what you created, you are a sun, glowing forever...')...considering, that the lecture 'Music of the spheres' of Leibniz Price winner Günther Hasinger was also illustrated by Kent Nagano and the Bavarian State Orchestra with Mozart's Jupiter Sinfonie in 2010 before the opening of the IMPRS Interdisciplinary Symposium 2010, New Frontiers in Science' in the Werner-Heisenberg- Institute/Max-Planck-Institut für Physik. On the way to harmony yoga, Qi Gong, TCM/Traditional Chinese Medicine, partly based on the I-Ging, aiming to bring Yin and Yang, Micro -an d Macro-cosmos into harmony, Ayurve-da, Bachor Mozart music may be helpful. Hubert Reeves reminds us, that Cosmos means universe but also order and beauty. Reeves sees Mozart in the center of the 8th day, embellishing the cosmos. According to Prof. Friedrich Weinreb the 8th day can be regarded as future. Searching a universal language Leibniz discovered already
Sanskrit, the I-Ging und the binary system inventing his calculation machine, which opened the way to the global information society, which can help to resolve problems, if both hemispheres of our brain are cooperating in a well-balanced way, generating order, harmony, beauty, empathy, responsibility and peace.Grace from above may recall Louis Pasteur's hope into our mind, that science and peace may triumph over wars and hatred, encouraging us and our children not only on Friday for future but also in our everyday life in our permanent endeavors for a peaceful Sustaining Life. Kosmos im Kopf (Cosmos in the head) was the title of an exposition in the German Hygiene-Museum 2000, recalling the mentioned persons in the introduction for healing aims into mind. In the Humboldt 2019 year the fractal Geometry of Nature, Sperry's, Luca Cavalli-Sforza's and Amartya Sen's insights enable us with the aid of mentioned pioneers and other ones like the Nobel Laureates Cornell, Crutzen, Ertl, Grünber g, Hänsch, Haroche, Hell, Jacob, Gell-Mann, Wieman \& Co. to discover America and other continents in their history without racism as fractals of the Earth history, being part of our solar system within the cosmic history. Saint Francis, name giver of San Francisco, praising the life giving sun, plants, animals and all humans as brothers and sisters may like Mozart, his little German Cantata and his Magic Flute, the German opera loved by all earth children, be recalled into the memory of us all. The Magic Flute adapted with paintings of children of the 3rd millennium earns perhaps to be sent into the space, containing children's wishes for peace on earth in harmony with the cosmos. The Program Papageno offers help for staying alive to those, who lost the motivation for it. See Konrad Frischeisen and Konrad Frischeisen Publishers in your Research Machine Epilogue: Lewis Mumford's and Viktor Frankl's books are like 'Staying alive', 'Sustaining Life' and Sperry's 'Science and Moral Priority' reinforcing hopes, that the freedom of art and science after Copernicus, Kepler, Galilei, Leibniz, Newton, Kant and Laplace will prevail. Nano-, Bio-and Laser technology, IT and fractal Geometry can be helpful, if the beauty and diversity of nature are leading the researchers also to deep insights into the unity of nature and humanity in the spirit of Humboldt with his responsible engagement for future generations. A video of Nobel Laureate Eric Cornell, explaining the Bose-Einstein condensate to young female researchers from India with a rose is encouraging, reminding us, that Columbus wanted originally find a way to India and that international cooperation can lead to excellent results.

\section{Acknowledgement}

None.

\section{Conflict of Interest}

No conflict of interest. 